Article

\title{
What Constitutes a Local Public Sphere? Building a Monitoring Framework for Comparative Analysis
}

\author{
Renate Fischer ${ }^{1, *}$, Alexa Keinert ${ }^{2}$, Otfried Jarren ${ }^{1}$ and Ulrike Klinger ${ }^{3}$ \\ ${ }^{1}$ Department of Communication and Media Research, University of Zurich, Switzerland; \\ E-Mails: r.fischer@ikmz.uzh.ch (R.F.), o.jarren@ikmz.uzh.ch (O.J.) \\ 2 Department of Political and Social Sciences, Freie Universität Berlin, Germany; E-Mail: a.keinert@fu-berlin.de \\ 3 European New School of Digital Studies, Europa-Universität Viadrina, Germany; E-Mail: klinger@europa-uni.de \\ * Corresponding author
}

Submitted: 30 December 2020 | Accepted: 8 June 2021 | Published: 23 July 2021

\begin{abstract}
Despite the research tradition in analyzing public communication, local public spheres have been rather neglected by communication science, although they are crucial for social cohesion and democracy. Existing empirical studies about local public spheres are mostly case studies which implicitly assume that cities are alike. Based on a participatory-liberal understanding of democracy, we develop a theoretical framework, from which we derive a monitor covering structural, social, and spatial aspects of local communication to empirically compare local public spheres along four dimensions: (1) information, (2) participation, (3) inclusion, and (4) diversity. In a pilot study, we then apply our monitor to four German cities that are comparable in size and regional function ('regiopolises'). The monitoring framework is built on local statistical data, some of which was provided by the cities, while some came from our own research. We show that the social structures and the normative assessment of the quality of local public spheres can vary among similar cities and between the four dimensions. We hope the innovative monitor prototype enables scholars and local actors to compare local public spheres across spaces, places, and time, and to investigate the impact of social change and digitalization on local public spheres.
\end{abstract}

\section{Keywords}

comparative research; local communication; local public spheres; participation and inclusion

\section{Issue}

This article is part of the issue "Spaces, Places, and Geographies of Public Spheres" edited by Annie Waldherr (University of Vienna, Austria), Ulrike Klinger (European University Viadrina, Germany) and Barbara Pfetsch (Freie Universität Berlin, Germany / Weizenbaum-Institute for the Networked Society, Germany).

(C) 2021 by the authors; licensee Cogitatio (Lisbon, Portugal). This article is licensed under a Creative Commons Attribution 4.0 International License (CC BY).

\section{Introduction}

Public communication is essential in democracies, a prerequisite for understanding political decisions and their consequences, enabling citizens to participate in society. Public communication acts are highly relational and thus constitute the public sphere as "a network for the communication of content and statements, i.e., opinions" (Habermas, 1992, p. 436, translation by the authors). The public sphere can be understood as a normatively and functionally demanding concept, based on various theoretical ideas of democracy and applied to different levels of society. In communication science, empirical studies of the public sphere have predominantly focused on the national level, such as thematic publics in mass media (e.g., Eilders et al., 2004; Ferree et al., 2002a) or social media (e.g., Bruns \& Highfield, 2016), or network structures of the public sphere (e.g., Wallaschek et al., 2020). A comprehensive, longitudinal, and cross-sectional perspective encompassing different levels and venues of the public sphere, such as encounters, public meetings, media and other intermediaries 
for enabling and organizing public communication acts, seemed only theoretically, but not empirically feasible (Neidhardt, 1989).

Less research exists regarding local public spheres. There are case studies focusing on public communication on specific topics (e.g., Friedland et al., 2007) or studies on local media ecologies (e.g., Coleman et al., 2016). While these studies focus on specific topics or media ecologies in single or a few cities and because results are thus hardly comparable to other studies in the field, our aim is to provide a framework which: a) provides an overview of the local public sphere which goes beyond a single media ecology; b) allows the comparison of a larger number of local public spheres by focussing on aspects of the local public sphere which can be easily quantified or where statistical data is widely available; and c) is intended to allow comparisons over time to measure changes in the local public sphere which happen for example due to technical, political, or societal change.

The focus of our article is on German cities, but the monitoring framework should be applicable to other cities in Western democracies as well since our four core dimensions are not specific for Germany but are normative demands on public spheres in participatoryliberal democracies in general. In Germany, much of the existing research on the local level dates back to the 1980s, when the introduction of private local radio and TV stations triggered a series of case studies (e.g., Bentele et al., 1990; Jarren et al., 1989). Since then, legal conditions, as well as the media environment on the municipal level, have changed, and legislators on the regional level as well as city administrations have introduced many participatory instruments of municipal governance (such as Bürgerbegehren and Bürgerentscheid; Kersting, 2008; Neumann, 2007, p. 359). In addition, new media have emerged: social media, neighborhood platforms, podcasts, city apps-just to name a few-which enable more inclusive forms of public communication, potentially turning citizens from mere information recipients to active participants in communication (Neuberger, 2009, p. 37).

Societal changes such as individualization and the rise of media platforms (digitalization) are transforming the public sphere on all levels, making it more inclusive, but also more fragmented-democratizing discourses but also leading to increasingly dissonant public spheres (Bennett \& Pfetsch, 2018). While there is much debate about this transformation, only a few comparative studies consider old and new elements of the public sphere, and even fewer on the local level. To our knowledge, there is no instrument to compare local public spheres over space and time. Measuring and monitoring the local public sphere could lead to new insight into the impact of social change, reveal any need for further research, and stimulate more local communication research. But how can we empirically measure local public spheres to compare them over time and space?

\section{Core Components of Local Public Spheres: Information, Participation, Inclusion, and Diversity}

Theories of the public sphere have been instrumental in our understanding of public communication and the emergence of public opinion. The public sphere is the social sphere where public matters are openly discussed, where different opinions and options for action are challenged and scrutinized, and where conflicting interests are negotiated. It is thus both a marketplace of ideas and an arena for competing opinions and interests. As such, the public sphere is a key category for the integration and development of modern societies (Neidhardt, 1989). In addition, as Theis-Berglmair (2015) points out, the public sphere is more than just the political public sphere: Integration and social cohesion can be promoted by discussions of societal issues as well.

Models of the public sphere can focus on structural aspects such as the different levels of social interaction, or the relationship of actors involved in the public sphere. Gerhards and Neidhardt (1990) proposed analyzing three different levels of the public sphere: (1) the level of encounters, where people meet by chance and discuss issues, for example, at work or on public transport, etc.; (2) public meetings where the topic as well as roles in communications, e.g., speaker, moderator, audience, are set; and (3) mass media where information is broadcast to a large, dispersed audience. These three levels are intertwined: On the encounter level, e.g., people might discuss topics they have heard about at public meetings or learned from the media; the media raises topics that are being discussed in public meetings or elsewhere in society. Through such processes, ideas, opinions, or frames can diffuse through the three levels and people can then get involved. A large and evergrowing body of literature has dealt with the question of how digital media and communication transform classic models of the public sphere and media systems but in the context of society at large, not the local level (e.g., Chadwick, 2017; Papacharissi, 2010; Reese \& Shoemaker, 2016; Schäfer, 2015).

Some models describe the political public sphere as an intermediary system between citizens and the state. The intermediary system consists of political parties, civic associations, interest groups, and the mass media, which aggregate, articulate, and organize the issues at stake (bottom-up) to explain, contextualize, and challenge the output of political decision-makers (top-down; Donges \& Jarren, 2017; Rucht, 1993). Nowadays, social media platforms, search engines, and messaging services are also part of this intermediary system-as digital or online intermediaries (e.g., Schmidt et al., 2019).

All attempts to model public spheres refer explicitly or implicitly to normative standards because the qualitative requirements of the public sphere are influenced by the underlying theories of democracy. The models of the public sphere can be grouped into four types: a representative-liberal model, a participatory- 
liberal model, a discursive model, and a constructionist model (Ferree et al., 2002a, 2002b; Martinsen, 2009). The framework we develop here is based on the normative characteristics of the participatory-liberal model of the public sphere, combining normative elements of a liberal understanding that has recurring, free and fair elections, and the regular exchange of governments at their core with normative elements that underline the inclusion and participation of citizens outside of elections. This theoretical approach goes beyond basic assumptions such as free media and freedom of speech and therefore allows to take account of participatory elements in the local public sphere in Germany and the hybrid media landscape described above. It also allows us to go beyond the contemporary approach of communication science which analyzes the local public sphere by focusing on media ecologies only. Instead, into our monitoring framework, we incorporate organizations of the civil society and other local structures that facilitate communication, participation, and inclusion. Our monitor is based on the participatory-liberal model, as this serves best our focus on the local public sphere in Western democracies. The participatoryliberal model emphasizes the (direct) engagement of all citizens in public life in contrast to the representativeliberal model in which voting is the major act of participation. At the same time, the participatory-liberal model is less demanding regarding public discourse practices than discursive models, which set high standards of civility, mutual respect, and emotional detachment. These standards can act as barriers to inclusive participation, even if this is not intended. The participatory-liberal model is less elite-focused than the representative-liberal model: It includes a broader section of the population without focusing predominantly on minorities as the constructionist model does (Ferree et al., 2002a, pp. 229-231).

From the participatory-liberal model of the public sphere and based on the work of Ferree et al. (2002a, $2002 b$ ), we derive four core dimensions for a framework to monitor and compare local public spheres: (1) information, (2) participation, (3) inclusion, and (4) diversity (see Figure 1). To assess the quality and the potential of local public spheres we specified the normative prerequisites for a strong public sphere accordingly:

1) Information: Citizens (and other stakeholders in a city's population) should be informed about relevant topics and different perspectives; they must have access to information that enables them to make informed political decisions.

2) Participation: Citizens should have multiple possibilities for political participation, to articulate their opinions, consent, or dissent.

3) Inclusion: Minorities, including those who are not eligible to vote, should be encouraged to participate in politics and society; their points of view, concerns, and interests should be heard and ideally represented in political decision making.
4) Diversity: A pluralist society should be represented in the local public sphere, enabling positive attitudes towards different and diverging perspectives and backgrounds.

All dimensions are valued equally and are linked to one another: people need information to participate in local public discourse; to articulate their needs and concerns, there need to be different formats that enable citizens to participate in their community's decision making; to guarantee the inclusion of minorities and the consideration of their demands, it is necessary to implement institutionalized procedures accordingly. If those requirements are met, we would expect to see a broad participation of the population in the local public sphere and as a result, we should see diversity in local media, the local parliament, and public administration, as well as the cultural public.

The local public sphere differs from national or transnational public spheres as "civic, public, and media ecologies" (Friedland et al., 2007, p. 46) are intertwined and "rooted in local communities" (p. 45), which serve as "schools of democracy" (p. 43). We, therefore, go beyond media ecologies and apply a non-media centric approach, aiming to measure other aspects of the community in relation to public communication, such as civil society engagement.

Based on these normative dimensions of local public spheres in Western democracies, we need to define categories, indicators, and variables that are accessible for empirical comparative research in the next step. These variables need to reflect on the information provided by local mass media and online platforms as well as on communication of the actors in the intermediary system. As implied by the specifics of the local public sphere and accounting for the digitalization of public communication and civic life, a monitoring framework should go beyond assessing mass media supply and information provided by city administrations, and also include the actors of the intermediary system and new digital intermediaries. The monitor includes variables to indicate mere opportunities to participate in the local public sphere (e.g., institutionalized opportunities for participation offered by the local government) as well as variables that indicate the extent to which any such opportunities are made use of (e.g., voter turnout). Indicators of the actual performance regarding the number of people participating in that opportunity have been chosen wherever comparable information was available.

\section{Monitoring the Local Public Sphere: Case Selection and Data Collection}

Our monitoring framework is structured along four dimensions, 12 categories, 36 indicators, and 84 variables. We have grouped the data into the four key dimensions derived from the participatory-liberal model of the public sphere and attempted to include data from all 
levels identified in Chapter 2. Dimensions and categories are displayed in Figure 1, while the complete set of indicators and variables is provided as a supplementary file in the online version of the article. The inner ring of Figure 1 depicts the four core dimensions, the outer ring denotes the three categories of each dimension. We have chosen this illustration to emphasize that each dimension is valued equally while also being interdependent.

To evaluate the information dimension, we analyze the local hybrid media landscape (Chadwick, 2011), the communication by local city administrations, and local actors of the intermediary systems such as political parties or welfare organizations that articulate and aggregate individual interests. In the participation dimension, we look at both institutionalized and non-institutionalized participation (Elstub, 2018; Rosanvallon, 2018; van Dijk \& Hacker, 2018; Weßels, 2018), as well as participation formats of civil society (Theocharis \& van Deth, 2018). The inclusion dimension presumes that no identifiable social groups should be excluded from the public sphere (Habermas, 1992). Thus, we focus on fora to include social groups in the political decision-making process and the support that local administrations and society offer to include vulnerable or disadvantaged groups. Concerning the diversity dimension, we take into consideration the representation of minorities in the public sector, cultural publics, as well as the diversity of media (Bohman, 1998; Zhang et al., 2013).

We then selected cases to empirically explore the four dimensions in four German cities, balancing the need for comparable units of analysis and the aim to develop a monitor, which can also account for variation, e.g., regional peculiarities. To identify cities of the same type regarding size and function within their respective regions, we referred to the regional statistical spatial typology RegioStar, developed for the German Ministry of Traffic and Infrastructure (Bundesministerium für Verkehr und digitale Infrastruktur, 2020). We selected four cities of the same type, 'regiopolises,' in different

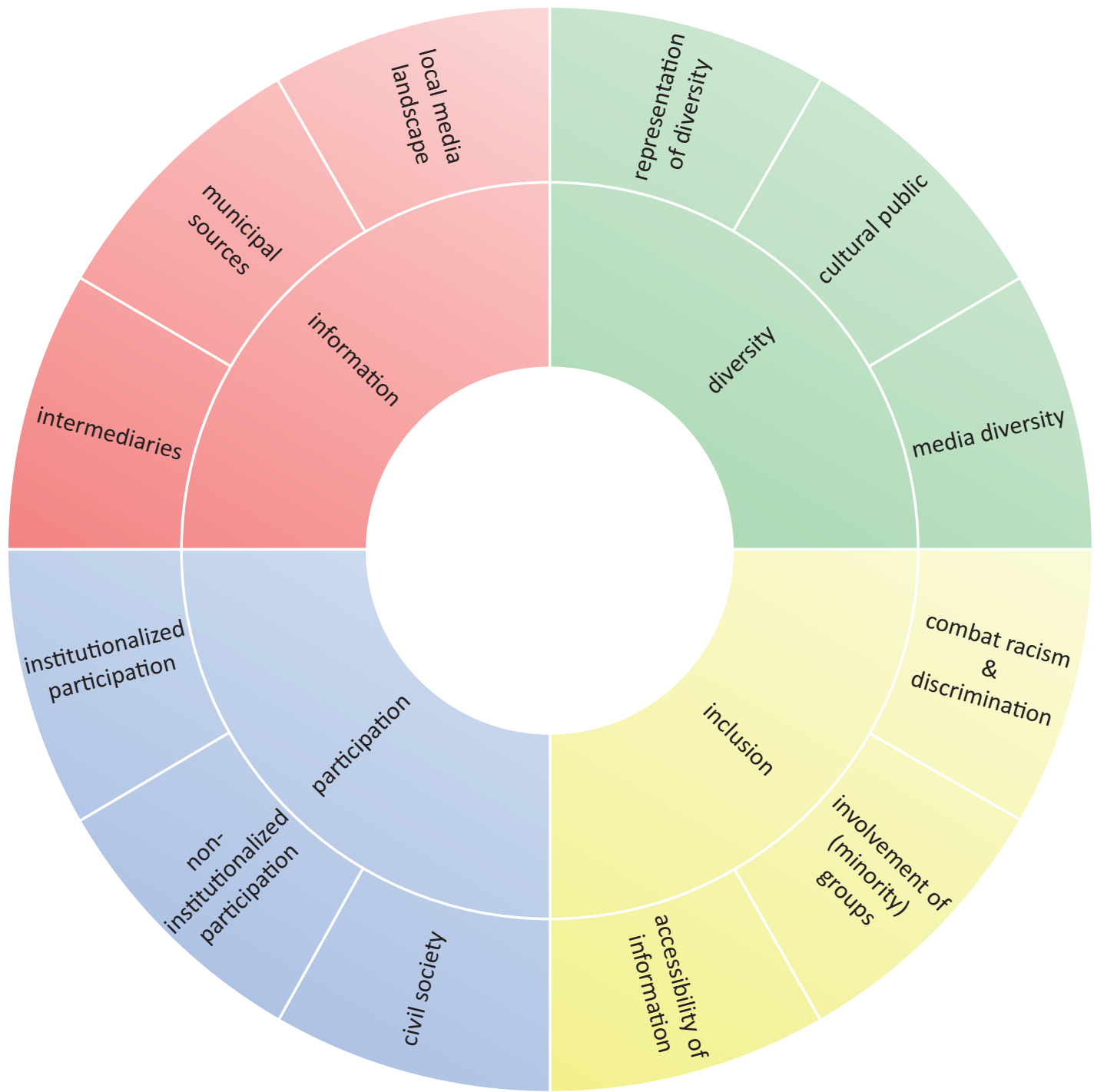

Figure 1. Monitoring the local public sphere: Dimensions and categories. 
geographical regions of Germany: Cottbus, Kassel, Osnabrück, and Pforzheim. 'Regiopolises' are cities with a population of at least 100,000 which lie outside the core area of metropolitan regions. They have an outstanding economic and cultural significance for their larger surrounding area (Aring \& Reuther, 2008; Regiopolregion Rostock, n.d.). In addition, we excluded state capitals, as this would add a further political dimension and take the focus from the local to the state level. We also excluded cities with an unusually high proportion of university students ('university towns'), as they would skew the demographics of the 'normal population,' for example, concerning media usage or voting behavior. We chose to include one city each from the north, south, west, and east of Germany to account for possible regional differences.

We followed a four-step approach to developing our monitoring framework: (1) operationalization, (2) selection of indicators, (3) data collection, and (4) construction of the framework.

\subsection{Operationalization}

In an iterative process, we identified and determined potential categories and indicators to operationalize our four dimensions of local public spheres. We reviewed the existing literature from various disciplines such as communication science, political science, sociology, and urban planning to detect potential indicators. At the same time, we located relevant actors as well as publicly available statistical data for our case cities to check for the availability of data. In multiple rounds of discussion within our project team and drawing on expert feedback, we considered, discarded, and then determined a range of potential categories and indicators.

\subsection{Selection of Indicators}

A preliminary collection of data on the four cities served to check the availability of data for the chosen indicators. Availability here means coverage, scalability, timeliness, and feasibility (see Montalto et al., 2019, p. 171, for a similar approach). In terms of coverage, we dismissed indicators for which we could not find data relating to all four cities in our sample. Since the core idea of a monitoring framework is to extend it to more than the initial four cities (scalability) and possibly to other countries, we did not include information from (qualitative and single) case studies. We compiled a unique collection of publicly available datasets for the years 2017 to 2020 (timeliness), preferring variables which had sufficient data to allow for a comparison over time. Since this monitor is designed for application outside of academia, once it is up and running, we sought to ensure easy data collection (feasibility), focusing on readily available data instead of that which needs to be gathered and processed using complex methods (e.g., content analyses).

\subsection{Data Collection}

Because we aim to include the different levels of social interaction, old and new intermediaries, as well as different forms of participation in the local public sphere, we used various sources for our data collection. The majority of the data used for the monitor was gathered by accessing existing data in various archives, annual reports, bureaus of statistics, and initiatives through desk or secondary research, while other information was collected for the specific purpose of the study through primary research. A central data source for our monitor was official statistics, as they usually meet all the availability criteria mentioned above. For the indicator of gender equality in the diversity dimension, for example, we used the indicator proportion of women in parliaments, collected under the United Nation's Sustainable Development Goals program and available at the public database regionalstatistik.de. An example of the use of public registers for our data collection is the register of associations (Vereinsregister), from which we have drawn information on the number of associations in a city, an indicator of the civil society in the participation dimension. We also used data provided by the municipal statistical offices, for example, to collect data on the number of theatre visitors, one aspect of the cultural participation indicator within the diversity dimension. Moreover, part of the data collected are search engine results. We used desk research mainly for the information dimension to capture the local media landscape, as data on most digital media (e.g., the number of local podcasts) are not systematically recorded in statistics. For the distribution of the local daily newspapers or advertising gazettes, we relied on systematic evaluations of the industry, e.g., the German Audit Bureau of Circulation (Informationsgemeinschaft zur Feststellung der Verbreitung von Werbeträgern) and the German Federal Association of Advertising Papers (Bundesverband Deutscher Anzeigenblätter). To map the digital communication of key actors of the intermediary system, we evaluated their presence on social media in the information dimension. To capture online participation in civil society we collected activity data on social networks, such as public groups on Facebook and neighborhood groups on Germany's largest digital neighborhood platform nebenan.de. We also made use of existing monitors and indices whenever we found overlaps with our categories, e.g., an evaluation of the procedural rules of citizens' initiatives (Bürgerbegehren) published by the University of Wuppertal in the participation dimension, or the European Charter for Equality of Women and Men in Local Life by the Council of European Municipalities and Regions (2006) for the category representation of diversity.

\subsection{Construction of the Framework}

Finally, we developed a scoring system for our monitoring framework: From the participatory-liberal model of 
the public sphere (presented in Chapter 2) we deduced that all four dimensions were to weigh equally; this also applies to the three categories subordinate to each of the dimensions. The first two levels of our model's hierarchy are shown as a sunburst diagram in Figure 1. The inner ring shows the four dimensions, the outer ring visualizes our 12 categories. In a full display of our monitor, there would be two additional rings: a third ring displaying the 36 indicators of our monitor, and an outermost ring displaying the 84 variables. The proportions in the sunburst diagram represent the assessment of the local public sphere: In the full circle, the four dimensions are each represented at 90 degrees which equals $25 \%$ of the total score. The dimensions are each divided into three equivalent categories. As we cannot describe all 36 indicators and 84 variables in detail, a list of all variables of our monitoring framework with a short description and their evaluation is available as a Supplementary File.

\section{Results: Similar Cities-Distinct Public Spheres}

To build and explore our monitoring framework, we gathered data on four German cities of similar size and function across different areas of Germany. We present these results to illustrate the application of the proposed monitor and as an example of what kind of insight could be gained by applying it to a larger number of cities. The most significant differences can be observed in the information and participation dimensions, whereas there was less variation in the overall results for inclusion and diversity (see Figure 2). While it is utopian to assume a city could reach a full score in all variables (because the dimensions represent normative ideal types), the value of monitoring (over time) and comparing (across cities) local public spheres regarding information, participation, inclusion, and diversity lies in identifying strengths and weaknesses, room for improvement, and best-practices.
As expected, we found variation across the cities in all four dimensions.

As the treemap diagram (Figure 3) shows, each city has its own 'profile' of the local public sphere. The size and position of the rectangles show how the city scored in the different categories. If a city had a full score in all categories, all rectangles would have the same size. Osnabrück achieved the highest scores across all dimensions, as shown by it having the largest area in the treemap diagram. In particular, Osnabrück performed comparatively well in the dimensions of information (red) and participation (blue), while in diversity (green) the other cities achieved better results. Even with almost identical overall scores for Pforzheim and Cottbus, the results show differences in their local public spheres. Similarities and differences in the categories of the four core dimensions are explained below.

\subsection{Information}

Local newspapers' readership figures are declining in all four cities. This has been a challenge for the newspaper industry for years, despite the continued relevance of local newspapers for local information. Only Kassel was able to score in this category, due to the comparatively high local newspaper circulation. We found free advertising gazettes and local radio stations in all four cities. Overall, Osnabrück was the frontrunner in the information dimension reaching $74 \%$ of the possible score, while Pforzheim reached only $39 \%$. The reason for Osnabrück's high score is its rich supply of alternative media channels: In Osnabrück, citizens can access magazines, blogs, online portals, podcasts as well as apps for local information-in contrast to all the other cities, which lacked at least one of these channels.

Our findings in the category of municipal sources show that all four cities have active accounts on various

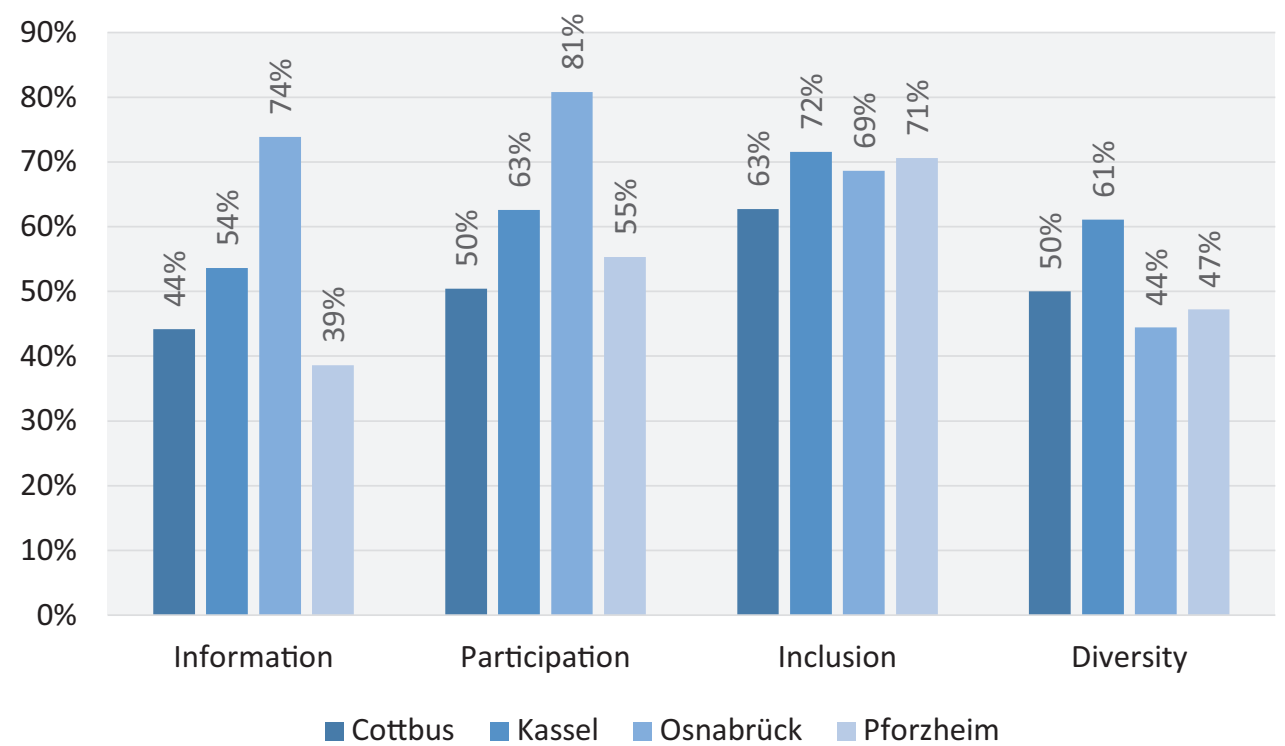

Figure 2. Results in the four dimensions in percentage for each city. 


\begin{tabular}{|c|c|c|c|c|c|c|c|c|c|c|c|c|c|c|c|}
\hline \multicolumn{4}{|c|}{ Osnabrück = 66\% } & \multicolumn{3}{|c|}{ Kassel = 61\% } & \multicolumn{5}{|c|}{ Pforzheim $=51 \%$} & \multicolumn{4}{|c|}{ Cottbus = 51\% } \\
\hline \multicolumn{2}{|c|}{ municipal sources } & \multicolumn{2}{|c|}{$\begin{array}{l}\text { institutionalized } \\
\text { participation }\end{array}$} & \multirow[b]{2}{*}{$\begin{array}{l}\text { cultural } \\
\text { public }\end{array}$} & \multirow{3}{*}{$\begin{array}{c}\text { repr... } \\
\text { of } \\
\text { diver... }\end{array}$} & \multirow{3}{*}{$\begin{array}{l}\text { local media } \\
\text { landscape }\end{array}$} & \multicolumn{2}{|c|}{$\begin{array}{l}\text { representati... } \\
\text { of diversity }\end{array}$} & \multicolumn{3}{|c|}{$\begin{array}{l}\text { institutiona... } \\
\text { participation }\end{array}$} & \multicolumn{3}{|c|}{$\begin{array}{l}\text { media } \\
\text { diversity }\end{array}$} & $\begin{array}{l}\text { municipal } \\
\text { sources }\end{array}$ \\
\hline \multirow{3}{*}{$\begin{array}{l}\text { local media } \\
\text { landscape }\end{array}$} & \multirow[b]{3}{*}{ int... } & \multirow{3}{*}{$\begin{array}{l}\text { non- } \\
\text { institu... } \\
\text { partici... }\end{array}$} & \multirow{3}{*}{$\begin{array}{l}\text { parti... } \\
\text { in civil } \\
\text { society }\end{array}$} & & & & \multirow{2}{*}{$\begin{array}{l}\text { media } \\
\text { diversity }\end{array}$} & \multirow{2}{*}{$\begin{array}{l}\mathrm{c} \ldots \\
\mathrm{p} \ldots\end{array}$} & \multirow{2}{*}{$\begin{array}{l}\text { non- } \\
\text { ins... } \\
\text { par... }\end{array}$} & \multirow{2}{*}{\multicolumn{2}{|c|}{$\begin{array}{l}\text { par... } \\
\text { in } \\
\text { civil } \\
\text { soci... }\end{array}$}} & \multirow{2}{*}{$\begin{array}{l}\text { cult... } \\
\text { public }\end{array}$} & \multirow{2}{*}{\multicolumn{2}{|c|}{$\begin{array}{c}\text { repr... } \\
\text { of } \\
\text { dive... }\end{array}$}} & \multirow{2}{*}{$\begin{array}{c}\text { local media } \\
\text { landscape }\end{array}$} \\
\hline & & & & media diversity & & & & & & & & & & & \\
\hline & & & & \multirow{3}{*}{$\begin{array}{l}\text { instituti... } \\
\text { participa... }\end{array}$} & \multirow{3}{*}{$\begin{array}{l}\text { parti... } \\
\text { in civil } \\
\text { soci... }\end{array}$} & \multirow{4}{*}{$\begin{array}{c}\text { involvement } \\
\text { of (minority) } \\
\text { groups }\end{array}$} & \multirow{3}{*}{\multicolumn{2}{|c|}{$\begin{array}{l}\text { involvement } \\
\text { of (minority) } \\
\text { groups }\end{array}$}} & \multirow{2}{*}{\multicolumn{3}{|c|}{$\begin{array}{l}\text { local media } \\
\text { landscape }\end{array}$}} & \multirow{2}{*}{\multicolumn{3}{|c|}{$\begin{array}{c}\text { institutionaliz... } \\
\text { participation }\end{array}$}} & \multirow{3}{*}{$\begin{array}{l}\text { involvement } \\
\text { of } \\
\text { (minority) } \\
\text { groups }\end{array}$} \\
\hline \multirow{3}{*}{$\begin{array}{c}\text { representati... } \\
\text { of diversity }\end{array}$} & \multirow[t]{3}{*}{$\begin{array}{l}\mathrm{m} . . \\
\mathrm{d} . . .\end{array}$} & \multirow{2}{*}{\multicolumn{2}{|c|}{$\begin{array}{l}\text { involvement of } \\
\text { (minority) } \\
\text { groups }\end{array}$}} & & & & & & & & & & & & \\
\hline & & & & & & & & & \multirow{2}{*}{\multicolumn{2}{|c|}{$\begin{array}{l}\text { munici... } \\
\text { sources }\end{array}$}} & \multirow[b]{2}{*}{ i... } & \multirow{2}{*}{\multicolumn{2}{|c|}{$\begin{array}{l}\text { particip... } \\
\text { in civil... }\end{array}$}} & n... & \\
\hline & & accessib & ity of... & non... & & & accessibil & ty... & & & & & & i... & accessibili... \\
\hline
\end{tabular}

Figure 3. Four cities: Four distinct 'profiles' of the local public sphere. Note: The size and order of the rectangles represent the score in the respective categories.

social media platforms. However, they demonstrate different degrees of openness to other digital instruments, such as e-government and open data, or are at different stages of their implementation. In the category of municipal sources, Osnabrück was the only city to score the maximum possible score.

The results regarding the information provided by political parties, welfare associations, and churches, are quite mixed. None of the cities reached more than $42 \%$ of the possible score. Local intermediary actors with more resources, like the Diocese of Osnabrück, seem to offer more online and offline information channels, which partly explains Osnabrück's comparatively good performance in this dimension. Other local intermediaries do not provide much information about their organizations which might reflect their lack of resources and their dependence on voluntary work.

\subsection{Participation}

In the category of institutionalized participation, all cities scored over $72 \%$. There was a growing voter turnout over the last two local elections in all cities. However, the level of the voter turnout in Pforzheim was rather low compared to other cities in the sample as well as compared to the average voter turnout for local elections in the state of Baden-Wurttemberg, where the city is located. But the city of Pforzheim scored high on the number of candidates, as their local elections proved highly competitive: In 2019, 520 candidates competed for just 40 seats in the local parliament. In this category, we also looked at other forms of institutionalized participation: As local popular initiatives and referenda are rather difficult to initiate due to legal restrictions set on the regional levels (Rehmet et al., 2018), all cities in our sample have found alternative ways for their population (eligible to vote or not) to be heard and to get involved. We found various institutionalized settings such as discussion groups, question time in the local parliament, or opportunities to participate in political assemblies held in suburbs regularly. In addition, there are forms of participatory budgeting and participation processes for building projects.

In the category of non-institutionalized participation, we found notable differences in the indicator 'protest': while Pforzheim, Osnabrück, and Kassel provide ample information on how to register protest marches (indicating the city administration sees them as a legitimate way to express different opinions, valuing the freedom of speech and offering simple, low-threshold registration), there is no information provided on the website of Cottbus. In Cottbus, protest marches need to be registered with the regional police and the registration process is less transparent.

Within the indicator of online participation, we analyzed the use of public Facebook groups and the use of the online neighborhood platform nebenan.de in the sample cities. The results show that public Facebook groups are used extensively in Pforzheim: There are 78 active public groups compared to $12-13$ groups in the other cities. In this context, it is also interesting that communication between large foreign-language population groups takes place via this channel: Roma, as well as the Polish and Romanian populations in Pforzheim, maintain very active forums on this channel, each with well over a thousand members.

\subsection{Inclusion}

In the category of access to information, we collected data on the city's public library (Vårheim et al., 2019) as well as the city's efforts to make their websites more accessible by providing documents in foreign languages, easy lan- 
guage (Leichte Sprache, directed to people with low reading competences) or audio formats. We found that most cities provide (some) information in foreign languages; few documents are provided in easy language, and none of the cities provide audio formats. However, Pforzheim offers an option to enlarge the contrast and size of the texts provided on their website for the visually impaired.

All cities attempt to include foreigners, seniors, young people, and the concerns of the different suburbs in the local political decision-making process. The most common form of group inclusion is the organization of representative bodies that have an institutionalized access to local politics to make their specific concerns and interests heard. In addition, to facilitate access for those directly affected, administrators often serve as commissioners (Beauftragte) who advocate for, and represent, the concerns of affected populations.

Fighting racism and discrimination is a challenging area, and it is difficult to find reliable data on the local level, e.g., statistics on hate crimes. Fortunately, the European Coalition of Cities against Racism (ECCAR) has established a network that tackles racism at the local level. Member cities have developed an action plan to fight racism and discrimination and engage in working groups to further develop the proposed measures. Membership is open even to smaller cities. We have included the ECCAR membership as well as six of the proposed actions (ECCAR, 2004) to combat racism and discrimination in our framework. So far, none of the four cities studied here is a member of this network.

\subsection{Diversity}

Our data on media diversity reflect the overall trend in Germany, with municipalities increasingly being served by only one local newspaper (Schmitt-Beck, 2014): Only in Pforzheim, are there still two local daily newspapers. However, media diversity can be sustained through other formats as well. In Cottbus, we found a newspaper for the Sorbian minority, various media produced by citizens (as amateurs) as well as a collaborative city wiki.

Regarding political diversity, specifically the number of political groups in the local parliament, we found distinct differences. This finding is affected by the history of the cities and indicates both pluralism and fragmentation. The citizens of Pforzheim are (currently) represented by 13 different groups and parties (across 40 seats in their local parliament), whereas the citizens of Kassel are represented by eight different groups and parties (in a parliament with 71 seats). The diversity of political groups surely influences political discussions and competition in local parliaments, whilst posing a range of challenges for policymakers. In three of four cities, the diversity of political representation indicated by the number of political groups increased from the previous to the current legislative term.

To sum up, even in cities that are similar in size and serve the same function in their specific region, there are manifest differences in the local public sphere. Future case studies could investigate the reasons for and the effects of those differences. Our framework for a comparative monitoring of local public spheres has already shown distinct variations across only four sample cities. As a next step, this framework should be scaled up and extended to compare more cities, cities of different types and sizes, and cities over time.

\section{Conclusion \& Discussion}

In this study, we developed a framework to monitor and compare local public spheres, based on a participatoryliberal normative understanding of democracy (Ferree et al., 2002b; Martinsen, 2009), which led to four core dimensions of the framework: (1) information, (2) participation, (3) inclusion, and (4) diversity. We operationalized these dimensions into 12 categories, 36 indicators, and 84 variables and collected a unique set of publicly available data and data sources. We aimed to provide an instrument that enables researchers to conduct comparative studies of the local public sphere on a larger scale. The monitoring framework could be a starting point to compare a substantial number of cities but it should also allow one to conduct longitudinal studies of the local public sphere. This could enable researchers to measure the developments and quantify changes in the local public sphere over time.

To test the applicability of the monitoring framework, we developed and tested it on four German cities of similar size and function. We were able to identify differences in the social structures of the local public spheres, discernible as distinct profiles of the cities (see Figure 3 ). The results can indicate in which dimensions and categories a city's local public sphere isnormatively speaking-stronger or weaker (compared to other cities or over time), but the monitor cannot evaluate the quality of discussions or the quality of the participatory processes. In those dimensions and categories where the monitoring framework indicated deficits or peculiarities of a city's local public sphere, we suggest case studies to investigate the reasons for them and to further analyze the quality of local public communication. Large scale comparisons could also provide insight into differences or similarities between local public spheres in distinct regions or countries and might even lead to a new categorization of local public spheres if distinct clusters were to be discovered.

There are of course limits to monitoring the public sphere based on statistics and other available data. While developing our monitor, we faced several challenges concerning data availability. Many data sources, whether public statistics, data on media use or results from representative surveys, are not available at the local level. In other words, they are lacking spatial depth and are often only available at the national level. Another reason for data being unavailable is the inconsistent data collection strategies between the federal states and 
cities (yielding incomparable data). Accordingly, some variables that might have been relevant for the monitor had to be discarded, for others, we looked for alternatives and workarounds. These proxies must be understood as "measurable aspects [that] have been selected to represent against notions or processes for which more comprehensive data is unavailable" (Montalto et al., 2019 , p. 175). For example, we could not get data on the number of demonstrations in a city within one year, so instead we assessed how easy and accessible (or difficult and inaccessible) it is to register a demonstration in the cities as a proxy variable. In this sense, it is important to underline that the monitoring framework-like any indices in general-cannot provide a perfect and comprehensive representation of the local public sphere of a city, but that it is one out of many possible ways of measuring a latent construct. Data access and the empirical analysis of local public spheres might become an even more severe challenge in the future, with increasing digitalization and importance of digital platforms. When local public communication is more and more dispersed and fragmented across black-boxed and algorithmically curated platforms, scholars will face a hard time to trace and monitor how publics and the public sphere emerge and develop. When public spheres become more and more dissonant (Bennett \& Pfetsch, 2018) and unedited (Bimber \& Gil de Zúñiga, 2020), this complexity, confusion, and lack of transparency also affects the local level.

For the further development of the monitoring framework, we suggest obtaining additional survey data from the cities regarding participation in local citizen's initiatives and actions taken by the local government to fight discrimination and racism. We would also suggest adding survey data on the perceptions of information access, which is not available but would have to be collected in the cities under study. Another important step would be to validate the indicators and variables in interviews or focus groups with actors from the city's administration, local journalists, local NGOs, and intermediary actors (local parties, churches, associations, etc.).

So far, the monitor is tailored to German cities classified as 'regiopoles.' It has yet to be adapted for a wider application to cities of different sizes or cities in other countries with different legal foundations. This could take into consideration that some indicators do not apply to smaller cities, such as local broadcasting, a local parliament, or a multilingual city website and that the possibilities of participation depend on the legal basis of the respective country. However, some of the variables were taken from European or International databases (e.g., data taken from the United Nations sustainable development goals) and could be used when adapting the monitor to other countries, some data such as the voter turnout will be available in all countries with local elections. In addition, our monitor demonstrates that applying a non-media centric approach and including data sources not typically investigated in communication studies produces interesting insights. Thus, we encourage research on the local level to explore new data sources and hope that the collection of indicators in our monitor framework serves as an inspiration.

Another challenge is the application of the monitor to conduct longitudinal studies. On the one hand, we aim to quantify changes in the local public sphere over time, on the other hand, it is challenging to develop a tool that measures a field that is in flux: Media and communication are constantly changing. The monitor probably needs to be adjusted from time to time. While we expect dimensions and categories to be more stable over time there will be the need for adjustment, especially on the level of variables where new media or new opportunities for local participation might develop in the near future and traditional ones lose their significance. To illustrate this claim, we can look at the indicator of online groups for engagement which belongs to the category of civil society in the dimension of participation: At the present, we take into account the existence of, and engagement in, public online groups on the most widely used social media and neighbourhood platforms. In our exploratory study, these were Facebook and nebenan.de. Those two networks could be easily replaced by other platforms. If new relevant platform types developed, it would be possible to add these as additional variables to the monitor. The weight of the indicator of online participation would still count as one third of the category civil society, but the weight of a single platform would diminish.

Even if monitoring the public sphere on a local level has its limitations due to the constricted data available for our four core dimensions, the monitoring framework is a highly relevant and valuable contribution both to the scientific debate about the local public sphere and for practitioners to analyze the structure and potential of their local public sphere. Ideally, the monitoring framework presented here will further encourage the collection of local data and research on public communication at the local level. This monitoring framework is a small, initial, but innovative step on the long road to a better understanding of local public spheres, and how they can be sustained and nurtured.

\section{Acknowledgments}

The article is based on the results of our research project "Local Public Spheres in Transition" which was funded by vhw-Bundesverband für Wohnen und Stadtentwicklung e.V. The authors would like to thank vhw for the financial support, and Bernd Hallenberg of vhw, the anonymous reviewers, as well as the academic editors for their valuable and constructive feedback on the manuscript.

\section{Conflict of Interests}

The authors declare no conflict of interests. 


\section{Supplementary Material}

Supplementary material for this article is available online in the format provided by the authors (unedited).

\section{References}

Aring, J., \& Reuther, I. (Eds.). (2008). Regiopolen: Die kleinen Großstädte in Zeiten der Globalisierung [Regiopolises: The small big cities in times of globalization]. JOVIS.

Bennett, W. L., \& Pfetsch, B. (2018). Rethinking political communication in a time of disrupted public spheres. Journal of Communication, 68(2), 243-253.

Bentele, G., Jarren, O., \& Kratzsch, U. (1990). Medienlandschaft im Umbruch: Medien- und Kommunikationsatlas Berlin [The changing media landscape: Media and communication atlas of Berlin]. Vistas.

Bimber, B., \& Gil de Zúñiga, H. (2020). The unedited public sphere. New Media \& Society, 22(4), 700-715.

Bohman, J. (1998). The globalization of the public sphere: Cosmopolitan publicity and the problem of cultural pluralism. Philosophy \& Social Criticism, 24(2/3), 199-216.

Bruns, A., \& Highfield, T. (2016). Is Habermas on Twitter? Social media and the public sphere. In A. Bruns, G. Enli, E. Skogerb $\varnothing$, A. O. Larsson, \& C. Christensen (Eds.), The Routledge companion to social media and politics (pp. 56-73). Routledge.

Bundesministerium für Verkehr und digitale Infrastruktur. (2020). Regionalstatistische Raumtypologie (RegioStaR) [Regional statistical spatial typology (RegioStar)]. https://www.bmvi.de/SharedDocs/DE/ Artikel/G/regionalstatistische-raumtypologie.html

Chadwick, A. (2011). The political information cycle in a hybrid news system: The British Prime Minister and the 'Bullygate' affair. The International Journal of Press/Politics, 16(1), 3-29.

Chadwick, A. (2017). The hybrid media system: Politics and power. Oxford University Press.

Coleman, S., Thumin, N., Birchall, C., Firmstone, J., Moss, G., Parry, K., \& Blumler, J. G. (2016). The mediated city: The news in a post-industrial context. Zed Books.

Council of European Municipalities and Regions. (2006). The European charter for equality of women and men in local life. https://www.ccre.org/docs/charte_ egalite_en.pdf

Donges, P., \& Jarren, O. (2017). Politische Kommunikation in der Mediengesellschaft: Eine Einführung [Political communication in the media society: An introduction] (4th ed.). Springer.

Eilders, C., Neidhardt, F., \& Pfetsch, B. (Eds.). (2004). Die Stimme der Medien: Pressekommentare und politische Öffentlichkeit in der Bundesrepublik [The voice of the media: Press commentary and the political public sphere in the Federal Republic of Germany]. VS Verlag für Sozialwissenschaften.

Elstub, S. (2018). Deliberative and participatory democ- racy. In A. Bächtiger, J. S. Dryzek, J. Mansbridge, M. Warren, \& S. Elstub (Eds.), The Oxford handbook of deliberative democracy (pp. 186-202). Oxford University Press.

European Coalition of Cities against Racism. (2004). 10 points action plan. https://www.eccar.info/en/ 10-point-action-plan

Ferree, M. M., Gamson, W. A., Gerhards, J., \& Rucht, D. (2002a). Shaping abortion discourse: Democracy and the public sphere in Germany and the United States. Cambridge University Press.

Ferree, M. M., Gamson, W. A., Gerhards, J., \& Rucht, D. (2002b). Four models of the public sphere in modern democracies. Theory and Society, 31, 289-324.

Friedland, L. A., Long, C. C., Shin, Y. J., \& Kim, N. (2007). The local public sphere as a networked space. In R. Butsch (Ed.), Media and public spheres (pp. 43-57). Palgrave Macmillan.

Gerhards, J., \& Neidhardt, F. (1990). Strukturen und Funktionen moderner Öffentlichkeit: Fragestellungen und Ansätze [Structures and functions of the modern public sphere: Research questions and approaches] (WZB Discussion Paper No. FS III 90-101). Wissenschaftszentrum Berlin.

Habermas, J. (1992). Faktizität und Geltung: Beiträge zur Diskurstheorie des Rechts und des demokratischen Rechtstaates [Facticity and validity: Contributions to the discourse theory of law and the democratic rule of law]. Suhrkamp.

Jarren, O., Storll, D., \& Bendlin, R. (1989). Lokale Medien und politische Kultur in Dortmund. Begleitforschung des Landes Nordrhein-Westfalen zum Kabelpilotprojekt Dortmund: Bd. 10 [Local media and political culture in Dortmund. Accompanying research to the introduction of cable TV]. Presse- und Informationsamt der Landesregierung Nordrhein-Westfalen.

Kersting, N. (2008). Innovative Partizipation: Legitimation, Machtkontrolle und Transformation. Eine Einführung [Innovative participation: Legitimization, power control and transformation. An introduction]. In N. Kersting (Ed.), Politische Beteiligung: Einführung in dialogorientierte Instrumente politischer und gesellschaftlicher Partizipation [Political participation: Introduction to dialogue-oriented instruments of political and social participation] (pp. 11-39). VS Verlag für Sozialwissenschaften.

Martinsen, R. (2009). Öffentlichkeit in der "Mediendemokratie"-Theorien und Befunde zur Medialisierung von Politik [Public sphere in the 'media democracy'-Theories and findings on the medialization of politics]. In F. Marcinkowski \& B. Pfetsch (Eds.), Politik in der Mediendemokratie [Politics in media democracies]. VS Verlag für Sozialwissenschaften.

Montalto, V., Tacao Moura, C. J., Langedijk, S., \& Saisana, M. (2019). Culture counts: An empirical approach to measure the cultural and creative vitality of European cities. Cities, 89, 167-185. 
Neidhardt, F. (1989). Auf der Suche nach Öffentlichkeit [In search of the public sphere]. In W. Nutz (Ed.), Kunst, Kommunikation, Kultur: Festschrift zum 80. Geburtstag von Alphons Silbermann [Art, communication, culture: Commemorative publication on the occasion of the 80th birthday of Alphons Silbermann] (pp. 25-36). Lang.

Neuberger, C. (2009). Internet, Journalismus und Öffentlichkeit [Internet, journalism, and the public sphere]. In C. Neuberger, C. Nuernbergk, \& M. Rischke (Eds.), Journalismus im Internet [Journalism in the internet] (pp. 19-105). VS Verlag für Sozialwissenschaften.

Neumann, P. (2007). Bürgerbegehren und Bürgerentscheid [Citizens' petitions and referenda]. In T. Mann \& G. Püttner (Eds.), Handbuch der kommunalen Wissenschaft und Praxis: Band 1 Grundlagen und Kommunalverfassung [Handbook of municipal science and practice: Volume 1 Fundamentals and municipal constitution] (3rd ed., pp. 353-377). Springer.

Papacharissi, Z. A. (2010). A private sphere: Democracy in a digital age. Polity.

Reese, S. D., \& Shoemaker, P. J. (2016). A media sociology for the networked public sphere: The hierarchy of influences model. Mass Communication and Society, 19(4), 389-410.

Regiopolregion Rostock. (n.d.). Definition of Regiopolis. https://www.regiopole.de/en/about-regiopolis/ definition

Rehmet, F., Sterk, T., Mittendorf, V., \& Zeybek, Y. (2018). Bürgerbegehrensbericht 2018 [Citizens' petition report 2018]. Mehr Demokratie. https://www. mehr-demokratie.de/fileadmin/pdf/2018-12-04_BBBericht2018.pdf

Rosanvallon, P. (2018). Good government: Democracy beyond elections. Harvard University Press.

Rucht, D. (1993). Parteien, Verbände und Bewegungen als Systeme politischer Interessenvermittlung [Political parties, associations, and movements as systems of political interest mediation]. In O. Niedermayer \& R. Stöss (Eds.), Stand und Perspektiven der Parteienforschung in Deutschland [The current state and perspectives of party research in Germany] (pp. 251-275). VS Verlag für Sozialwissenschaften.
Schäfer, M. S. (2015). Digital public sphere. In G. Mazzoleni (Ed.), The international encyclopedia of political communication (pp. 1-7). Wiley.

Schmidt, J.-H., Merten, L., Hasebrink, U., Petrich, I., \& Rolfs, A. (2019). How do intermediaries shape newsrelated media repertoires and practices? Findings from a qualitative study. International Journal of Communication, 13, 853-873.

Schmitt-Beck, R. (2014). Wie informieren sich die Bürger über die Politik ihrer Stadt? [How do citizens inform themselves about the politics of their city?] In J. W. van Deth (Ed.), Demokratie in der Großstadt: Ergebnisse des ersten Mannheimer Demokratie Audit [Democracy in a big city: Results of the first Mannheim democracy audit] (pp. 51-80). Springer.

Theis-Berglmair, A. M. (2015). Öffentlichkeit und öffentliche Meinung [Public sphere and public opinion]. In R. Fröhlich, P. Szyszka, \& G. Bentele (Eds.), Handbuch der Public Relations [Handbook of public relations] (pp. 399-410). Springer.

Theocharis, Y., \& van Deth, J. W. (2018). Political participation in a changing world: Conceptual and empirical challenges in the study of citizen engagement. Routledge.

van Dijk, J., \& Hacker, K. L. (2018). Internet and democracy in the network society. Routledge.

Vårheim, A., Skare, R., \& Lenstra, N. (2019). Examining libraries as public sphere institutions: Mapping questions, methods, theories, findings, and research gaps. Library \& Information Science Research, 41(2), 93-101.

Wallaschek, S., Starke, C., \& Brüning, C. (2020). Solidarity in the public sphere: A discourse network analysis of German newspapers (2008-2017). Politics and Governance, 8(2), 257-271.

Weßels, B. (2018). Politische Integration und politisches Engagement [Political integration and political engagement]. In Datenreport 2018: Ein Sozialbericht für die Bundesrepublik Deutschland [Data report 2018: A social report for the Federal Republic of Germany] (pp. 350-357). Bundeszentrale für politische Bildung.

Zhang, W., Cao, X., \& Tran, M. N. (2013). The structural features and the deliberative quality of online discussions. Telematics and Informatics, 30(2), 74-86.

\section{About the Authors}

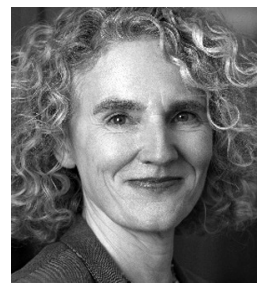

Renate Fischer (MA) is a PhD Student at the University of Zurich. She has worked as a Research Assistant in the Department of Communication and Media Research in the project "Local Public Spheres in Transition." Her research focuses on the transformation of the political public sphere caused by societal and technological changes and the effects on journalism, political communication, and democracy. 


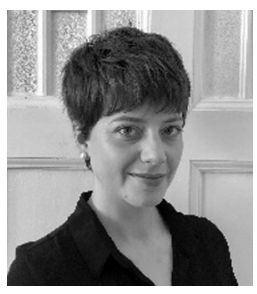

Alexa Keinert (MA) is a PhD Candidate at the Institute of Media and Communication Studies at Freie Universität Berlin. As a Research Assistant in the project "Translocal Networks: Public Sphere in the Social Web" at the Collaborative Research Center "Re-Figuration of Spaces" (CRC 1265), she investigates the geographical structure and spatiality of digital public communication. She is interested in the emergence of public communication, communication geography, and mixed methods research.

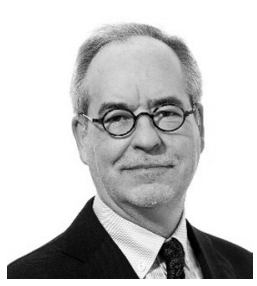

Otfried Jarren (Prof. em. Dr.) is currently a Professor with special duties at the University of Zurich. He was previously Professor of Communication Studies at the University of Zurich (1997-2019), and Professor of Journalism at the University of Hamburg (1989-1997). He directed the Hans Bredow Institute for Media Research at the University of Hamburg (1995-2001). He is Honorary Professor of Journalism and Communication Studies at FU Berlin (since 2016), and President of the Swiss Federal Media Commission (since 2013). He was the winner of the Schader Prize in 2018.

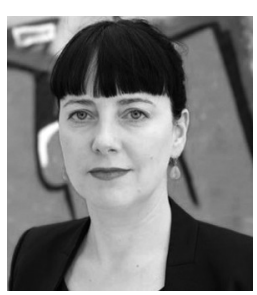

Ulrike Klinger (Prof. Dr.) is a Professor for Digital Democracy at the European University Viadrina. She is also an Associated Researcher at the Weizenbaum Institute for the Networked Society in Berlin. She was Professor for Digital Communication at FU Berlin and Head of the research group on "News, campaigns and the rationality of public discourse" at the Weizenbaum Institute. Her research focuses on political and digital communication-the transformation of digital public spheres, the role of digital media in election campaigns, and the impact of technologies on public communication. 